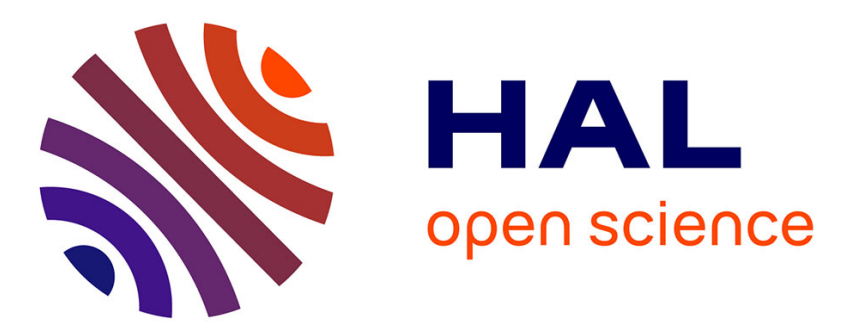

\title{
A new damsel-dragonfly of the small family Selenothemistidae from the Late Jurassic of China (Odonata, Isophlebioptera)
}

Diying Huang, Chenyang Cai, André Nel

\section{- To cite this version:}

Diying Huang, Chenyang Cai, André Nel. A new damsel-dragonfly of the small family Selenothemistidae from the Late Jurassic of China (Odonata, Isophlebioptera). Journal of Paleontology, 2018, 92 (6), pp.1049-1053. 10.1017/jpa.2018.33 . hal-01992823

\section{HAL Id: hal-01992823 \\ https: / hal.sorbonne-universite.fr/hal-01992823}

Submitted on 24 Jan 2019

HAL is a multi-disciplinary open access archive for the deposit and dissemination of scientific research documents, whether they are published or not. The documents may come from teaching and research institutions in France or abroad, or from public or private research centers.
L'archive ouverte pluridisciplinaire HAL, est destinée au dépôt et à la diffusion de documents scientifiques de niveau recherche, publiés ou non, émanant des établissements d'enseignement et de recherche français ou étrangers, des laboratoires publics ou privés. 


\title{
A new damsel-dragonfly of the small family Selenothemistidae from the earliest Late Jurassic of China (Odonata: Isophlebioptera)
}

Diying Huang ${ }^{1}$, Yanzhe $\mathrm{Fu}^{1,2}$, Jian $\mathrm{Gao}^{1}$ \& André $\mathrm{Nel}^{3}$

${ }^{1}$ State Key Laboratory of Palaeobiology and Stratigraphy, Nanjing Institute of Geology and Palaeontology, Chinese Academy of Sciences, Nanjing 210008, People's Republic of China. ${ }^{2}$ University of Science and Technology of China, Hefei 230026, PR China

${ }^{3}$ Institut de Systématique, Évolution, Biodiversité, ISYEB - UMR 7205 - CNRS, MNHN, UPMC, EPHE, Muséum national d'Histoire naturelle, Sorbonne Universités, 57 rue Cuvier, CP 50, Entomologie F-75005, Paris, France.

*Author for correspondence, e-mails:dyhuang@nigpas.ac.cn, anel@mnhn.fr

\begin{abstract}
Jurathemis incompletus gen. et sp. nov., sixth new genus and species of the small Jurassic family Selenothemistidae, is described from the earliest Late Jurassic of China. It differs from the other representatives in the narrower hindwing cubito-anal area. The fossil discovered from the Middle-Upper Jurassic Yangshuzhuang Fm. near the Anyao Village, Jiyuan City, China. The same layer have been yielded very rich insect fossils that reveal the distribution of the famous Yanliao biota in the central-east China. The present new species is the first formally described fossil insects from this locality.
\end{abstract}

Key words: Odonata; Epiproctophora; Isophlebiida; Yangshuzhuang Fm.; Yanliao biota

\section{Introduction}


The Mesozoic ‘anisozygopteran’ clade Isophlebiida Bechly, 1996 is quite diverse with more than 48 described genera, especially the two families Campterophlebiidae Handlirsch, 1920 and Isophlebiidae Handlirsch, 1906 in which numerous new genera and species have been recently described, mainly from China (see Fossilworks: Gateway to the Paleobiology Database at http://fossilworks.org/). It is not the case for the more inclusive isophlebiopteran clades Euthemistidae Pritykina, 1968, Parazygoptera Bechly, 1997, and Selenothemistidae Handlirsch, 1939, that comprises ca. 25 described genera. These last groups comprise relatively small and delicate damsel-dragonflies, compared to the Isophlebiida. Thus their lower diversity is possibly the result of a taphonomic bias. They are mainly known from Europe, Central Asia and China.

Here we describe a new genus and species belonging to the small family Selenothemistidae, from the lowest Upper Jurassic Yangshuzhuang Formation at the locality near the Anyao Village, Chengliu Township, Jiyuan City, Henan Province, China (Fig. 1). The outcrop located at the top of Yangshuzhuang Fm. and very close to the boundary of the Yangshuzhuang and Ma’ao formations. Both Yangshuzhuang and Ma’ao formations. Have been considered as the Middle Jurassic (Deng et al., 2003). In recent research, Huang (2018) indicate Yangshuzhuang Fm. correlate to Haifanggou Fm. which yielded very rich exceptional fossil including various insects (Huang, 2016) and the Ma’ao Fm. correlate to Tiaojishan Fm. in north China. Therefore, the age of Yangshuzhuang Fm. would mainly assigned with the Middle Jurassic but its upper section is the earliest Late Jurassic. The Ma'ao Fm. correspond to Oxfordian and Kimmeridgian. The fossil insects from the Yangshuzhuang Fm. were assigned within the assemblage Samarura - Necrocercopis yananensis (Deng et al., 2003) including the insects from the Haifanggou Fm. at Liaoning Province, the Jiulongshan Fm. at Hebei Province, the Yan'an Formation at Shaanxi Province, and the Yangshuzhuang Fm. at Henan Province. Some contents from this fossil insect assemblage are likely found from the Yangshuzhuang Fm. such 
as Yangshuzhuangia jurassica (Deng et al., 2003) but they are never described. Thus no any valuable information on fossil insects known from this locality to date.

\section{Material and methods}

The type specimen was prepared with a sharp knife under microscope. Maps and line drawings were drafted with CorelDRAW X7 graphic software. Photographs were taken with a digital camera attached to a Zeiss Discovery V20 microscope.

We follow the wing venation nomenclature of Riek and Kukalová-Peck (1984) as modified by Nel et al. (1993) and Jacquelin et al. (2018), and the Epiproctophoran classification of Bechly (1995, 1997, 2016). Wing abbreviations are as follows: Arc= arculus; Ax = primary antenodal crossvein; $\mathrm{C}=$ costa $\mathrm{CuA}=$ cubitus anterior; $\mathrm{CuP}=$ cubitus posterior; $\mathrm{d}=$ discoidal cell; IR = intercalary radial veins; $\mathrm{MA}=$ median anterior; $\mathrm{MP}=$ median posterior; $\mathrm{N}=$ nodus; ' $\mathrm{O}$ ' = oblique vein; $\mathrm{Pt}=$ pterostigma; $\mathrm{RA}=$ radius; anterior; $\mathrm{RP}=$ radius posterior; $\mathrm{sd}=$ subdiscoidal space; $\mathrm{Sn}$ = subnodal crossvein. All measurements are given in millimeters

\section{Systematic palaeontology}

\section{Order Odonata Fabricius, 1793}

Suborder Epiproctophora Bechly 1996

\section{Clade Isophlebioptera Bechly, 1996}

\section{Family Selenothemistidae Handlirsch, 1939}

List of species. Caraphlebia antarctica Carpenter, 1969 (Antarctica), Paraliassophlebia chengdeensis Hong, 1982 (China), Selenothemis liadis Handlirsch, 1920 (Germany), Sinothemis difficilis Huang et al. 2018 (China), Turanothemis nodalis Pritykina, 1968 (Kazakhstan), Jurathemis incompletus gen. et sp. nov. (China). The family is recorded from the Early to Middle-Late Jurassic. 
Note. Cowley (1942) indicated that the two genera Dialothemis Cowley, 1942 (D. dubia (Handlirsch, 1939)) and Liadothemis Handlirsch, 1906 could belong to the Selenothemistidae, but Bechly (2016) excluded them from this family.

\section{Genus Jurathemis gen. nov.}

Type species. Jurathemis incompletus sp. nov.

Etymology. Named after the Jurassic age of the fossil and the suffix -themis (ancient Greek Titaness, personification of the divine order), frequently employed for taxa in this family. Gender masculine.

Diagnosis. Hindwing characters only. Subdiscoidal cell enlarged and with a bulged posterior margin; a large cell basal of subdiscoidal cell in anal area; postdiscoidal space between MP and MA narrow, with only one row of cells between them; no secondary antenodal crossveins; distal side (MAb) of discoidal cell 3.6 as long as basal side); a long space between CuP and distal crossvein between AA and MP+CuA; narrow anal area with only one cell below subdiscoidal cell; RP2 arising distinctly distal of subnodus; no antefurcal crossveins in space between RP and MA basal of midfork; nodal and subnodal veinlets aligned and oblique; MA not zigzagged distal of level of nodus.

\section{Jurathemis incompletus sp. nov.}

\section{Figure 2}

Material. Holotype NIGP169577, stored at the Nanjing Institute of Geology and Palaeontology CAS, Nanjing, China. Only holotype was found, an incomplete hindwing, without counterpart. The fossil preserved in the green-grayish mudstone.

Etymology. Named after the incomplete state of preservation of the type specimen.

Diagnosis. Wing rather small, ca. $5 \mathrm{~mm}$ wide. 
Age and outcrop. The earliest Late Jurassic (early Oxfordian); uppermost of the Yangshuzhuang Fm. near the Anyao Village, Chengliu Township, Jiyuan City, Henan Province, China.

Description. The basal half of a hindwing, without trace of coloration, probably hyaline. Length of fragment $15.7 \mathrm{~mm}$, probable length of wing ca. $21 \mathrm{~mm}$, width of wing $4.8 \mathrm{~mm}$; distance from base to arculus $3.5 \mathrm{~mm}$, from arculus to nodus $6.2 \mathrm{~mm}$; petiole short but distinct, $0.75 \mathrm{~mm}$ long, $1.2 \mathrm{~mm}$ wide; base of RP3/4 (midfork) $3.4 \mathrm{~mm}$ from arculus and $3.0 \mathrm{~mm}$ from nodus, base of IR2 very close to it; only the primary antenodal crossveins Ax0, Ax1 and Ax2 present, so secondary antenodals, distance from wing base to Ax1 2.5 mm, from Ax1 to Ax2 $1.3 \mathrm{~mm}$; arculus between Ax1 and Ax2, closer to Ax2; nodal $\mathrm{Cr}$ and subnodus well aligned and oblique; four postnodal crossveins preserved, not aligned with the three preserved postsubnodals; base of RP2 two cells, $3.1 \mathrm{~mm}$ distal of subnodus; MAa not zigzagged below nodus and even more distally in its preserved part; no crossvein between arculus and midfork in space between RP and MA; only three antesubnodal crossveins; median and submedian space free, CuP opposite Ax1; AA bent distal of CuP, crossvein distally closing submedian space well distal of CuP, $0.75 \mathrm{~mm}$ distal; submedian cell large and broad, $1.3 \mathrm{~mm}$ long, $0.75 \mathrm{~mm}$ wide, with a bulged posterior margin; free $\mathrm{CuA}$ before its fusion with AA short, $0.2 \mathrm{~mm}$ long; postdiscoidal area narrow, $0.9 \mathrm{~mm}$ wide distal of discoidal cell, with one row of cells; space between MP and CuA slightly broader than postdiscoidal space; a large cell basal of subdiscoidal cell in anal area; only one row of cells between subdiscoidal cell and posterior wing margin; two rows of cells between $\mathrm{CuA}$ and posterior wing margin in its distal part; one row of cell between RP3/4 and MAa in their preserved parts; discoidal cell large, broad, quadrangular, with distal side (MAb) 3.6 times as long as basal side, basal side $0.25 \mathrm{~mm}$ long, MAb 0.9 mm long; oblique vein 'O' and pterostigma not preserved. 


\section{Discussion}

Although fragmentary, this fossil can be attributed to the Isophlebioptera Bechly, 1996 because of the following characters: hindwing subdiscoidal cell enlarged and with a bulged posterior margin, correlated with a unique course of the anal vein AA ('pseudo-anal-loop') which is strongly bent towards the posterior wing margin at the CuP-crossing; postdiscoidal space between MP and MA very narrow, with only one row of cells between them; distal of Ax2 all antenodal crossveins between the costal margin and ScP are suppressed. Jurathemis gen. nov. shares with the Selenothemistidae Handlirsch, 1939 the distal side (MAb) of the hindwing discoidal cell twice (or more) as long as basal side (= posterior part of arculus), but it differs from all the genera currently in this family in the shape of the hindwing subdiscoidal cell that has a long space between $\mathrm{CuP}$ and distal crossvein between $\mathrm{AA}$ and $\mathrm{MP}+\mathrm{CuA}$, plus a narrow anal area with only one cell below subdiscoidal cell (Hong, 1983; Nel et al., 1993; Kelly and Nel, 2018; Huang et al., 2018).

An attribution of Jurathemis to the Parazygoptera Bechly, 1997 could be supported by the RP2 arising distinctly distal of subnodus, but this character is also present in the Chinese genus Paraliassophlebia Hong, 1983, currently attributed to the Selenothemistidae. Within the Parazygoptera, the Sphenophlebiidae Bechly, 1997 have hindwing discoidal cells narrower than in Jurathemis, while Jurathemis shares with the Euparazygoptera Bechly, 1997 the absence of antefurcal crossveins in the space between RP and MA basal of the midfork (a character also present in the Selenothemistidae). Jurathemis has not the main synapomorphy of the Triassolestoidea Tillyard, 1918, viz. nodal and subnodal veinlets not aligned and separated by a short kink in RA (in the subgroup Triassolestinae, the nodus and subnodus are more or less aligned but perpendicular to RA, unlike in Jurathemis). Note that Sogjutella mollis Pritykina, 1980 has MAb twice as long as basal side of discoidal cell, a MAa not zigzagged, an anal area similar to that of Jurathemis, but it differs from Jurathemis in the nodal and subnodal veinlets 
not aligned, and the base of IR2 below nodus (Pritykina, 1980). In the other subclade of the Euparazygoptera, Jurathemis shows strong similarities with the Asiopteridae Pritykina, 1968 (especially a similar shape of cubito-anal area), but the synapomorphy of this family 'IR2 distally zigzagged' is unknown in Jurathemis. The synapomorphy 'MA distally zigzagged' (distal of level of nodus) is absent in Jurathemis. The third synapomorphy 'hindwing discoidal cell quadrangle-like, with an oblique distal side Mab' is present in Jurathemis but also in the Selenothemistidae. Furthermore, all the Asiopteridae for which the hindwing discoidal cells are known (Asiopterum Pritykina, 1968, Oreopterella Pritykina, 1968, Oreopteron Pritykina, 1968), have a distal side MAb less than twice as long as basal side, while it is three times as long in Jurathemis (Pritykina, 1968).

Similar discoidal cells are also present in the two Cenozoic zygopteran families Sieblosiidae Handlirsch, 1907, Dysagrionidae Cockerell, 1908, and in the isophlebiopteran Pseudostenolestidae Garrouste and Nel, 2015. In these three families, the subdiscoidal cell is quite narrower than in Jurathemis and in the Selenothemistidae, and the cubito-anal area is quite broad (Garrouste and Nel, 2015). Also the Sieblosiidae have a very particular subnodus vertical or of inverted obliquity.

\section{Conclusion}

If Jurathemis shares some similarities with the Asiopteridae, it currently better fits in the Selenothemistidae for the shared specialized discoidal cell. It is the sixth genus currently attributed to this Jurassic family, in accordance with the earliest Late Jurassic of the type outcrop.

The new species Jurathemis incompletus gen. et sp. nov. is the first fossil insects described from the Yangshuzhuang Fm. We recently discovered a very diverse and rich palaeoentomofauna in this locality. Its age corresponds to the Daohugou biota, the early 
assemblage of the famous Yanliao biota (Huang, 2015, 2016). Therefore, the further study of the insects of the Yangshuzhuang Fm. would be very helpful for understanding the distribution and evolution of the insects from Yanliao biota.

\section{Acknowledgements}

We sincerely thank two anonymous referees for their useful comments and corrections on the first version of the paper. This study was supported by the National Key Research and Development Program of China (Grant No. 2016YFC0600406), the Strategic Priority Research Program (B) (Grant No. XDB26000000 and XDB18000000) of the Chinese Academy of Sciences, and the National Natural Science Foundation of China (Grant No. 41688103).

\section{References}

Bechly, G. (1996) Morphologische Untersuchungen am Flügelgeäder der rezenten Libellen und deren Stammgruppenvertreter (Insecta; Pterygota; Odonata), unter besonderer Berücksichtigung der Phylogenetischen Systematik und des Grundplanes der Odonata. Petalura Special Volume, 2, 1-402.

Bechly, G. (1997) New fossil Odonata from the Upper Triassic of Italy, with a redescription of Italophlebia gervasutti, and a reclassification of Triassic dragonflies. Rivista del Museo Civico di Scienze Naturale E. Caffi, 19, 31-70.

Bechly, G. (2016) Phylogenetic systematics of Odonata. - homepage on Internet site: https://bechly.lima-city.de/phylosys.htm

Cowley, J. (1942) Descriptions of some genera of fossil Odonata. Proceedings of the Royal Entomological Society of London, (B), 11, 63-78.

Deng, S., Yao, Y., Ye, D., Chen, P., Jin, F., Zhang, Y., Xu, K., Zhao, Y., Yuan, X. \& Zhang, S. (2003) The Jurassic System of North China (I): A stratigraphic Overview. Petroleum Industry Press, Beijing, 399 pp. 
Garrouste, R. \& Nel, A. (2015) New Eocene damselflies and first Cenozoic damsel-dragonfly of the isophlebiopteran lineage (Insecta: Odonata). Zootaxa, 4028, 354-366.

Hong, Y.-C. (1983) Beijang zhongzhu Inoshi kunchong huashi [Middle Jurassic fossil insects in North China.] Geological Publishing House, Beijing: 223 pp. [in Chinese with English summary.]

Huang, D.-Y. (2015) Yangliao biota and Yanshan movement. Acta Palaeontologica Sinica, 54, $501-546$.

Huang D.-Y. (2016) Daohugou Biota. Shanghai Scientific \& Technical Publishers, Shanghai, $332 \mathrm{pp}$.

Huang, D.-Y. (2018) Jurassic integrative stratigraphy and timescale of China. Science in China: Earth Science. https://doi.org/10.1007/s11430-017-9268-7

Huang, Diying, Cai, Chenyang \& Nel, A. (2018) A new damsel-dragonfly of the small family Selenothemistidae from the Late Jurassic of China (Odonata: Isophlebioptera). Journal of Paleontology, 92, 1049-1053.

Jacquelin, L., Desutter-Grandcolas, L., Chintauan-Marquier, I., Boistel, R., Zheng, Daran, Prokop, J. \& Nel, A. (2018) New insights on basivenal sclerites using 3D tools and homology of wing veins in Odonatoptera (Insecta). Scientific Reports, 8, 1-7.

Kelly, R.S. \& Nel, A. (2018) Revision of some damsel-dragonflies (Odonata, Liassophlebiidae and Anglophlebiidae new family) from the Triassic/Jurassic of England and Antarctica. Journal of Paleontology, 92, 1035-1048.

Nel, A., Martínez-Delclòs, X., Paicheler, J.-C. \& Henrotay, M. 1993. Les 'Anisozygoptera' fossiles. Phylogénie et classification (Odonata). Martinia Numéro Hors Série, 3, 1-311.

Pritykina, L.N. (1968) Strekozy Karatau (Odonata). [Dragonflies from Karatau (Odonata)]. p. 26-55. In: Panfilov, D.V. (coord.), Yurskie Nasekomye Karatau. [Fossil insects from Karatau]. Academy of Sciences of the S.S.S.R., Nauka, Moscow, 252 pp. [in Russian.] 
Pritykina, L.N. (1980) [New fossil Odonata from the Mesozoic of Central Asia.] pp. 119-131. In: Dolin, V.G., Panfilov, D.V., Ponomarenko, A.G. and Pritykina, L.N. [Mesozoic fossil insects.] Naukova Dumka, Kiev, 1-134. [In Russian.]

Riek, E.F. \& Kukalová-Peck, J. (1984) A new interpretation of dragonfly wing venation based upon Early Carboniferous fossils from Argentina (Insecta: Odonatoidea) and basic characters states in pterygote wings. Canadian Journal of Zoology, 62, 1150-1166. 

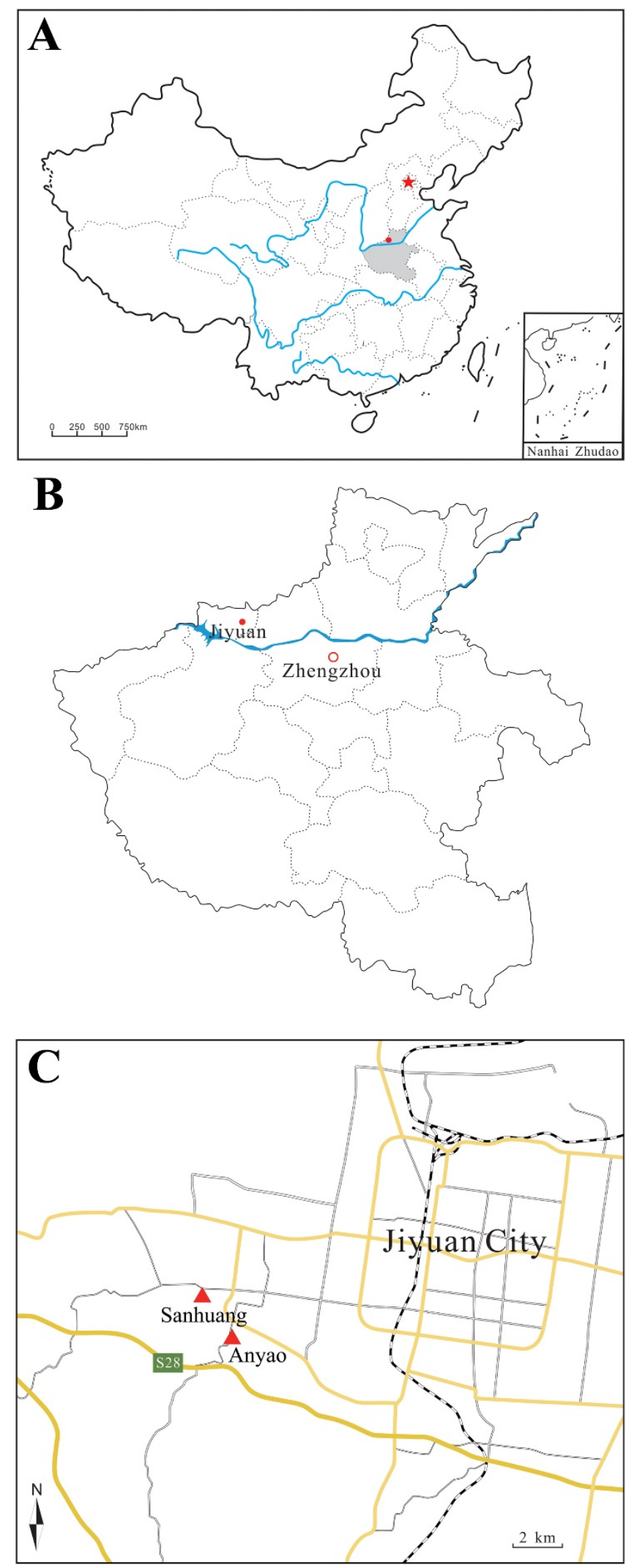

FIGURE 1. The fossil locality maps of Jurathemis incompletus gen. et sp. nov. A, the position of fossil locality in China; B, enlargement from A, showing the location in Henan Province; C, the detailed map of the fossil locality. 


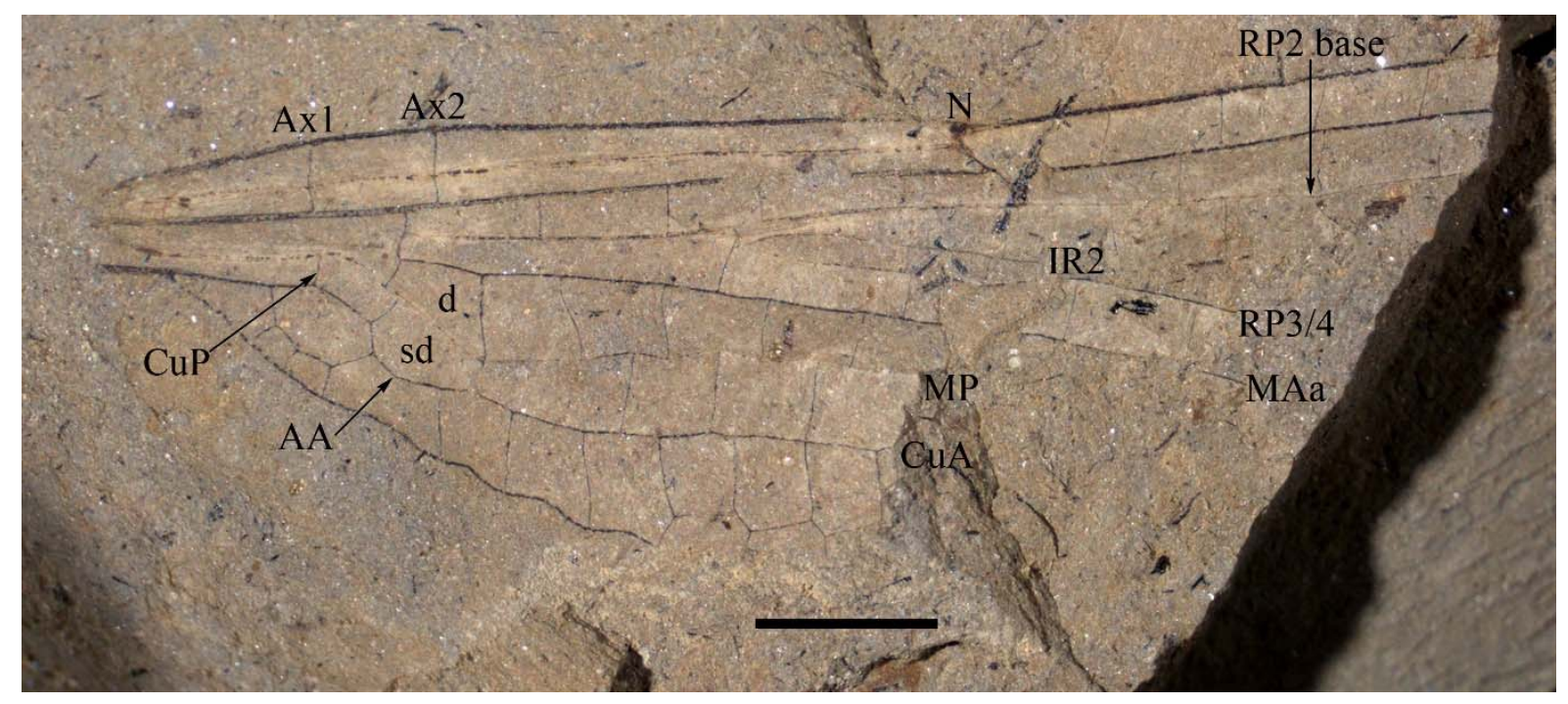

FIGURE 2. Jurathemis incompletus gen. et sp. nov., holotype NIGP169577, photograph of hindwing (scale bar $=2 \mathrm{~mm}$ ). 


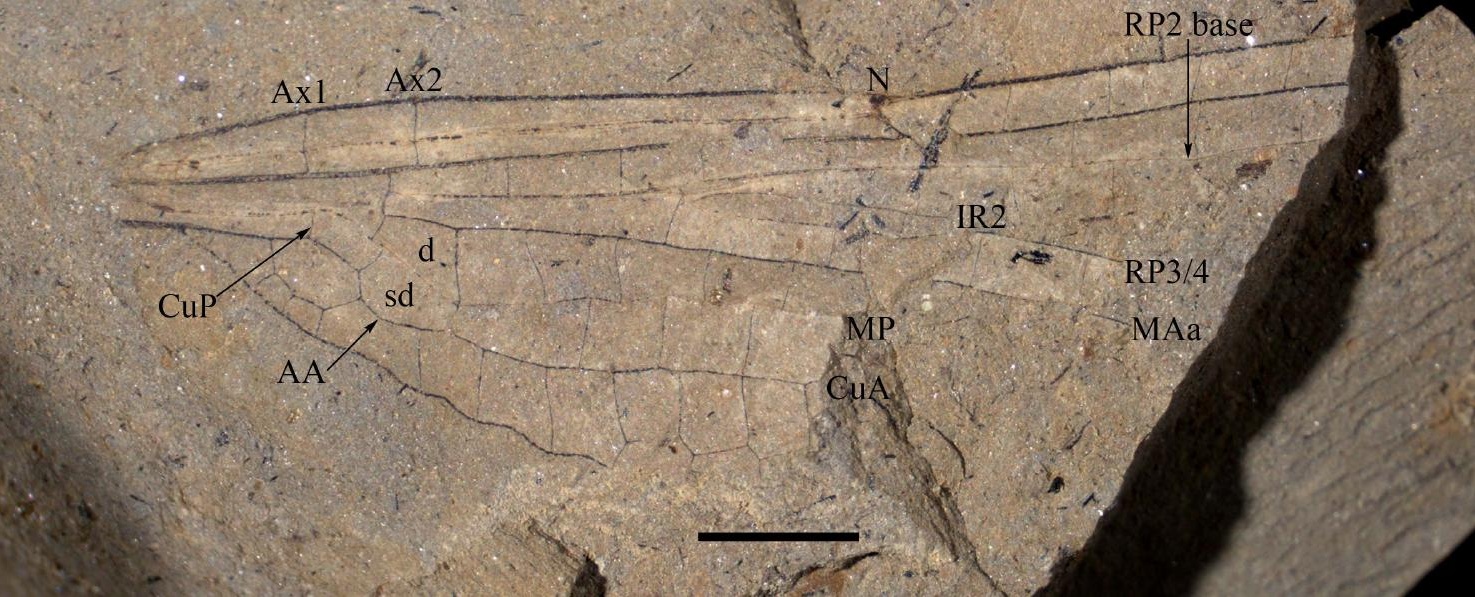

